Global Conferences Series:

Social Sciences, Education and Humanities (GCSSSEH), Volume 2, 2019

The $2^{\text {nd }}$ International Conference on Sustainable Development \& Multi-Ethnic Society

DOI: https://doi.org/10.32698/GCS.0173

\title{
Curriculum of History Education in Malaysia, Finland and Republic of Turkey: A Comparative Literature Analysis
}

\author{
Mahira Mayadi ${ }^{1}$, Mohd Mahzan Awang ${ }^{2}$, Abdul Razaq Ahmad ${ }^{3} \&$ Anuar Ahmad $^{4}$ \\ ${ }^{1234}$ Faculty of Education, MALAYSIA \\ E-mail: iamsickofu93@yahoo.com
}

\begin{abstract}
History education has been labelled as a rigid, boring and least favoured subject amongst students especially primary and secondary school students. Classroom practice is said to lack consistency and often based on date's conceptualization of the construct. Scholars have introduced variety of conceptual and practical approaches to attract student's interest in learning history but this still lead to persistent confusion about the nature, purpose and significance of learning history. The purpose of this conceptual paper is to analyse the progress of history education in Malaysia, Finland and Republic of Turkey. We focus on the goals set by the curriculum, the common issues in learning history and the the method used in teaching and learning history in these countries. We aim to highlight the challenges at implementing the best history education curriculum in Malaysia, Finland and Republic of Turkey and where further study is needed.
\end{abstract}

Keywords: History, history education, scholars, education, method, teaching

\section{Introduction}

History refers to events or events that have actually occurred in the past; it is the science of analysing past events in the relations of place-time and cause-effect. Thus, the sense of history is linked to time and events. According to Bury, history cannot be put a value as it focuses on empirical approach and uses sistematic method which is the inevitable validity and the reliability. Scholars need to do meticulous research on the subject to achieve the ideal degree of validity and reliability.

History is a study of humanity in the past and this understanding will be a guidance and a lesson for humans to lead a better life in the future. He further noted that history is a dialogue on the events that have happened in the past and that are still happening in the present. In his context, historian and its subject are related to one another hence making the history itself special and influential.

\section{The Concept of History Education}

History education is one of the necessary elements for the progress and development of society. History Education in Malaysia aims to foster and strengthen the country's loyalty and identity as Malaysian citizens and citizens of the world. Through knowledge and appreciation of the nation's history and the relevant history of the country abroad, students will 
be able to understand the state of society and the country and its relationship to world's history. This effort aims to create a sense of unity between Malaysia and other nations around the world. History education can also create a shared memory of history as a framework for national awareness and international understanding amongst Malaysians. History education is the key of the development of a sense of identity within a society. Emphasis on this aspect is certainly the agenda for a sovereign nation. It is not too much to say that historical education is a catalyst for the progress of a nation and of civilization. Indeed, the history of the ancient civilizations is a reflection and lesson to the nations of the world today. In building the strength of a nation, it is important for historical interest to be restored in order to strengthen and even further the development of the nation.

Educational system in Finland is known as the best in the world, as Finland has won kudos both for its consistently strong performance on the PISA - an international survey that evaluates education systems worldwide - and for its success in promoting broad equality of opportunity, a healthy work-life balance, and a high degree of autonomy by highly educated teachers.

In Finland, the national core curriculum is a framework around which local curricula are designed. The national core curriculum contains the objectives and core contents of teaching for all school subjects; including history and also describes the mission, values, and structure of education. It describes the conception of learning and goals for developing the learning environment, school culture and working methods.

The National Core Curriculum for Basic Education as well as the one for Upper Secondary Schools (2003) emphasize basically similar values, such as human rights, equality, democracy, respect for the diversity of nature and sustainable development and acceptance of cultural diversity, all of which are significant in the teaching of the humanities, both for their subject-specific aims and contents. It also describes the conception of learning and goals for developing the learning environment, school culture and working methods (The Finnish National Board of Education, 2011). This gives the core curriculum a dual role: on one hand it is an administrative steering document, on the other a tool for teachers to develop their own pedagogical praxis. This means that while Finnish education relies on its documents and paperwork in terms of its content and aims, it also allows their teachers to have pedagogical freedom in choosing their materials, approach and method including in history education.

On the other hand, the curriculum of history education in Republic of Turkey focuses on social progresses and for the community to establish a link between the past and the future. Turkish famous leader; Mustafa Kemal Atatürk once said, it is harder to teach history than to make it, because history should be taught objectively. History takes the societies' progress and awareness as a target and for that reason it reconciles the past and the present with the future. Besides, the curriculum believes that it should count the students' opinion when a discussion takes place during teaching and learning session. It helps the students to fully understand history education.

During Mustafa Kemal Atatürk era, he wanted to set up a strong, modern and secular nation state, and he believed that history was one of the important instruments in creating it. For this reason, history education and historiography were seen as tools for transmitting Turkish identity and nationalist ideas among Turkish society.

Turkish history education is one of the necessary elements for the progress and development of society. History; is the science of analyzing past events in the relations of place-time and cause-effect. Most important role of the history is to illuminate the present and open the way to explore the future by showing the evolution of humanity. History shows the cultural, political and economic evolution of the humanity.

\section{Issues and Method}

The common issue in history education in most countries is about the way this subject is taught. Teacher-centered history learning is not as effective as expected. Teaching of indoctrinated and non-creative, one-way teachers does not create opportunities for interaction between teachers and students. This has made the process of teaching and learning (R\&D) history so tedious and boring for students. Teachers still maintain the traditional methods in the classroom. Teachers lack the expertise in delivering the latest pedagogy. The chalk and talk method emphasizing one-on-one interaction and memorization of facts has led to History being seen as the "dead man of curriculum". The negative attitude of the teachers has caused them to fail to internalize the student's mind to be more intellectual and this has led to the students being less focused during teaching-learning session.

The contents of the History curriculum are packed with facts and dates that students need to remember. Learning the history subject means having to memorize facts and dates that are so stressful. This makes history subject less attractive to students. For students, these subjects are more likely to talk about outdated events and do not see what to consider in studying History. In addition, there are parents who find this subject unimportant and a favorite subject of 
literary students [13]. The History curriculum focuses more on memorizing facts and stereotype. According to Tan Sri Alimuddin Mohd Dom, former Director-General of Education Malaysia, the approach of memorizing history needs to be changed in more interesting ways and it should make the students able to think critically about an event.

Meanwhile, in Finland, their history education system is a little bit different than the other, where Finnish teenagers are expected to assume responsibility for their own learning. This expectation is embedded in the structure of the high school program. Secondary education is modular, with several short terms per year, and students design their own programs, working from a slate of required introductory courses and toward the goal of preparing for the national matriculation exam. The benefits when students are in charge of their own learning caused them to shape the basic structure of the lessons; a significant portion of the teaching was done, not by teachers, but by students. This means that teacher acts as the observer while the students will carry out the presentation by searching information in the reference books and on the internet. During presentation, teacher will gently prod certain groups to flesh out the details or deepen their analysis. In essence, teacher provides the intellectual structure and quality control for a lesson taught largely by students.

Nevertheless, the Finnish curriculum is less ambitious in its work with written primary sources but notably strong in its teaching of media literacy and data interpretation. This means that while Finnish students capably read documents and contextualize them with relevant background information, they tend to understand the sources as information rather than evidence.

In Turkish history education system, the issue has been quite similar with one faced in Malaysia, whereas the method used in teaching history has been teacher-based; the teachers use traditional "chalk and talk" method. The history curriculum in Turkey was first based on a problem-solving approach. Nevertheless, the majority of history teachers did not implement this curriculum, but continued to teach history in a traditional way.

However, since 2010, history and the other curriculum subjects were re-designed in the light of the constructivist approach, which requires teachers and schools to create an active learning environment. According to the new approach, students were encouraged to construct new insights based on their previous learning and experience. The idea was that they should be given the opportunity to learn by themselves and be provided with a rich learning environment. In history lessons in particular, students are expected to use primary and secondary sources, letters, pictures, multimedia, ICT and technology to enhance the understanding of the subject.

\section{Challenges and Suggestions}

There are quite a number of challenges we need to face in order to implement values of history education among students. The first is the impression of parents on this history subject itself has been negative throughout the years. They do not see history education as important as other subjects; science, mathematics, thus paying little attention on their children's interest on this subject. The resolution to change the mindset of the society about the importance of history education has been thoroughly implemented and is still ongoing.

Next, the challenge to implement an upright history curriculum is to educate the teachers in terms of their capability to teach history in the best way. The problem lies on the fact that these teachers do not have enough information about what history education is, and how to teach history lessons in an active way. Thus, Turkish education system decided that every history teacher need to have proper degree and knowledge before they are allowed to teach history subjects. The curricula of teacher education programs called non-thesis master's programs were divided into three main parts, and in the new system, teacher candidates were required to take courses in three different areas: pedagogy, knowledge of subject and knowledge of general culture. This is important to make sure that the teacher has proper education and knowledge in order to teach the subject in the best way possible.

Another challenge to prosper the goals set by the history education curriculum in these countries is to unite the people under history education. For example, Malaysia is a well-known country with its cultural diversity and this unique element needs to be flourished through a proper history education system, parallel to its aim which is to create a sense of unity between Malaysia and other nations around the world. The effort to unite these diverse races in this country has been proven challenging over time, where sensitive issues involving the races keep occurring. Nevertheless, history curriculum in Malaysia is keep improving to make sure that these unique elements can continue to be nourished.

Various efforts have been undertaken to improve history education curriculum to implement good values among the people of various races in Malaysia as well as Finland and Republic of Turkey. The first effort is the practice of cross-cultural education module drafted by Malaysia's Unity and National Integrity Department, collaborated with Malaysia's Ministry of Education since 
2016. This module focuses on the ideas, effort, and discussion and plans to integrate various races and ethnics in this country through cross-cultural education module. History education should implement this module in its curriculum for example, planning a joint programs or events involving students from national schools and vernacular schools. This will help the students from various races and ethnics to be more understanding and respectful towards other cultures and sensitivity.

Secondly, teachers who abide the responsibility to teach history education to students need to have proper education and knowledge before they are given the permission to teach this subject. For example, teachers need to have at least a degree in related course and have complete pedagogy training in related field. This is a very important matter because it ensures that the students get the right knowledge in the best way possible. In addition, the students could enjoy learning history if the teachers know the best method and techniques in teaching this subject to make it more fun but at the same time informative.

Next, if we talk about Finnish education, there is a reason why it has been one of the best education systems in the world. While Finnish education has been focusing on students' participation in its subjects, it is soaring upward for better system when it comes to education. In 2020, Finland is set to abolish teaching system according to subjects but to implement phenomenon-based learning system. In Phenomenon Based Learning (PhenoBL) and teaching, holistic real-world phenomena provide the starting point for learning. The phenomena are studied as complete entities, in their real context, and the information and skills related to them are studied by crossing the boundaries between subjects. For example, historical elements will be taught as holistic topics like human, European Union, media and technology, water or energy. The starting point differs from the traditional school culture divided into subjects, where the things studied are often split into relatively small, separate parts.

Phenomenon based learning focuses on integrating different subjects and themes using meaningful methods such as inquiry learning, problem-based learning, project learning and portfolios. These different subjects will be mixed and discussed thoroughly through deepened topics. This way, students will get the core of knowledge and more understanding of the lesson. Phenomenon based learning will also attract students' interest in learning particular topics including topics that are related to history studies because this method encourages students to be more responsible in their own learning plus it encourages the use of technology such as multimedia, ICT and technology.
Other than that, the issue that we tend to overlook is one with the parents who feel that history education is not as important as other academic education. History education is assumed as a lesser subject thus it is often being neglected by society. The importance of learning history is beyond learning basic incidents that happened in the past, but it is also to strengthen the relationship among the people in society, especially in a country like Malaysia where the people are divided into diverse ethnics and races. Thus, it is important for scholars to make an effort in changing the mindset of the society and the skeptical opinion about history education. For example, parents and the members of society should be encouraged to join programs or events that are made by institution when it comes to enhancing history education curriculum. This will strengthen the relationship between the members of society of different races and ethnics.

\section{Conclusion}

In general, history education curriculum in Malaysia, Finland and Republic of Turkey have a few similarities in terms of the goals, aims, challenges and methods, but there are apparent differences as well. To date, there are many efforts which have been undertaken to achieve the goal of history education curriculum in each country and the efforts are still ongoing.

The responsibility to enhance and improve curriculum of history education in every way possible should not be shouldered solely by the teachers but also by each of everyone in the society. The cooperation of everyone in the society is very well needed in order to make sure the aim of history education curriculum can be achieved

\section{References}

[1] Abdul Razaq Ahmad dan Andi Suwirta. (2007) Sejarah dan Pendidikan Sejarah: Perspektif Malaysia Dan Indonesia. Bandung: Historia Utama Press

[2] Bury, J.B. (2010). The Idea of Progress: An Inquiry into its Origin and Growth. Online Distributed Proofreading Team.

[3] Carr, E.H (1961). What is History? University of Cambridge and Penguin Books.

[4] Emperical Research on History Education in Turkey: An Overview of Key Issues, Methods and OutcomesYearbook of ISHD: 53-67

[5] Hanninen et. al. (2014). A New Finnish National Core Curriculum for Basic Education and Technology as an Integrated Tool for Learning. Sense Publisher, Rotterdam. 
[6] Hartini Husain. 2006. Achievement and attitudes of students in teaching the subject through a computer. Masters Thesis. Facultyof Education. UKM

[7] Hasberg, W \& Erdmann E. (2012). History Teacher Education. Wochenschau Geschichte

[8] Jukka Rantala (2012). How Finish Adolescents Understand History: Disciplinary Thinking in History and Its Assessment among 16-Year-Old Finns. Education Sciences 2 (2012): 193-207.

[9] Kasmuri, A. (2009). Pendidikan Sejarah di Malaysia: Isu Penerapan Nilai dan Patriotisme [History Education in Malaysia: The Implementation of Value and Patriotism Issue]. National University of Malaysia.

[10] Kasmuri, A. (2009). Pendidikan Sejarah di Malaysia: Isu Penerapan Nilai dan Patriotisme [History Education in Malaysia: The Implementation of Value and Patriotism Issue]. National University of Malaysia.

[11] Koruroglu, A. \& Baskan, GA. (2013). An Overview and History Education in Republic of Turkey and Turkish Republic of Northern Cyprus. Procedia - Social and Behavioral Sciences, 89, 786 - 791.

[12] Krokfors, Hurmerinta \&Vitikka. (2012). Tthe Finnish Core Curriculum. Sense Publishers, Rotterdam.

[13] Pasi Sahlberg (2014). Finnish Lessons 2.0: What Can the World Learn from Educational Change in Finland: $2^{\text {nd }}$ Edition. Teachers College Columbia University New York and London.

[14] Pasi Silander (2015). Phenomenon Based Learning in Finland. $\quad$ Retrieved from http://www.phenomenaleducation.info/phenomenonbased-learning.html on August 31, 2019.

[15] Pasi Silander (2015). Phenomenon Based Learning in Finland. $\quad$ Retrieved from http://www.phenomenaleducation.info/phenomenonbased-learning.html on September 1, 2019.

[16] Professor Alun Munslow. (2001). What History is? Retrieved from http://www.history.ac.uk/ihr/Focus/Whatishistory/munslo w6.html on August 31, 2019.

[17] Robiah Sidin. (1994). Pendidikan di Malaysia. Kuala Lumpur: Fajar Bakti.

[18] Sabran \& Muthusamy (2016). Cross - Cultural Module: Jabatan Perpaduan Negara. Serdang: Universiti Putra Malaysia

Selected Publications: Turkish History Teachers Perceptions of Primary Sources in History Textbooks The New Educational Review 21 (2010): 71-78 